\title{
Impact of oral conditions on the quality of life of adolescents in a rural area of Brazil
}

\author{
Tatiany V. Roque, Isabela Q. Magnani, Saul M. Paiva, Lucas G. Abreu \\ Universidade Federal de Minas Gerais, Faculdade de Odontologia, Departamento de Saúde Oral da Criança e do \\ Adolescente. Belo Horizonte, Brasil.
}

\begin{abstract}
The aim of this study was to assess the impact of oral conditions on the oral health-related quality of life (OHRQoL) of early adolescents aged 11 to 14 years in the rural population of a Brazilian municipality. Adolescents attending public schools in the municipality participated in the study. OHRQoL was measured using the short Brazilian version of the Child Perceptions Questionnaire (CPQ11-14) with four domains: oral symptoms, functional limitations, emotional wellbeing and social wellbeing. A higher score indicates a more negative perception of the adolescent regarding his/her OHRQoL. Oral conditions such as dental caries, malocclusion and dental trauma were evaluated using DMTF index, Dental Aesthetics Index (DAI) and Andreasen criteria, respectively. The variables sex and age, number of siblings, parents' schooling, family monthly income, number of times of tooth-brushing/day and visits to the dentist/year were also evaluated. Descriptive analysis and regression models were performed. Of the 202
\end{abstract}

participants, 94 (46.5\%) were female and 108 (53.5\%) were male. Adolescents from low-income families $(p=0.042)$ and with more severe malocclusion $(p=0.037)$ scored higher in the CPQ11-14. Those with severe malocclusion scored higher in the emotional wellbeing domain $(p=0.009)$. Females scored higher than males in the oral symptoms domain $(p=0.002)$. Adolescents from low-income families scored higher in the social wellbeing domain ( $p=0.006)$. Malocclusion negatively affected the OHRQoL of adolescents from a Brazilian rural area, mainly regarding emotional wellbeing. Negative repercussions were also observed among females and adolescents whose families had lower income.

Received: December 2020; Accepted: February 2021.

Keywords: quality of life - oral health - rural population adolescent.

\section{Impacto de condições bucais na qualidade de vida de adolescentes em uma área rural do Brasil}

\begin{abstract}
RESUMO
O objetivo deste estudo foi avaliar o impacto de condições bucais na qualidade de vida relacionada à saúde bucal (QVRSB) de adolescentes de 11 a 14 anos da população rural de um municipio brasileiro. Adolescentes que estudavam em escolas públicas do município participaram do estudo. QVRSB foi avaliada usando a forma curta da versão brasileira do Child Perceptions Questionnaire (CPQ11-14) com quatro dominios: sintomas bucais, limitações funcionais, bem-estar emocional e bem-estar social. Um escore mais alto indica uma percepção mais negativa do adolescente com relação à sua QVRSB. Condições bucais, tais como cárie dentária, má oclusão e traumatismo dentário foram avaliados com o indice CPOD, Índice Estético Dental (IED) e os critérios de Andreasen, respectivamente. As variáveis sexo e idade dos adolescentes, número de irmãos, escolaridade dos pais, renda familiar mensal, número de vezes de escovação dos dentes/dia e visitas ao dentista/ano também foram avaliadas. Análise descritiva e modelos de regressão foram realizados. Dos 202 participantes,
\end{abstract}

94 (46,5\%) eram meninas e 108 (53,5\%) eram meninos. Adolescentes cujas famílias tinham uma renda mais baixa $(p=0,042)$ e com má oclusão mais severa $(p=0,037)$ obtiveram escores mais altos no CPQ11-14. Aqueles com má oclusão severa obtiveram um escore mais alto no domínio de bemestar emocional $(p=0,009)$. Com relação ao sexo do individuo, meninas tiveram um escore mais alto no domínio sintomas bucais $(p=0,002)$. Adolescentes cujas familias tinham uma renda mais baixa obtiveram um escore mais alto no domínio de bem-estar social $(p=0,006)$. A má oclusão afeta negativamente a QVRSB de adolescentes de uma área rural brasileira, principalmente o bem-estar emocional. Repercussões negativas também foram observadas entre meninas e adolescentes cujas famílias tinham uma renda mais baixa.

Palavras-chave: qualidade de vida - saúde bucal - população rural-adolescente. 


\section{INTRODUCTION}

Oral health-related quality of life (OHRQoL) was defined by Locker and Allen in 2007 as the effect of oral conditions on aspects of everyday life that are important to people. Those effects are of sufficient magnitude, whether in terms of frequency, severity or duration, to affect the individual's perception of his/her life in general ${ }^{1}$. It is a complex, dynamic construct that includes multidimensional indicators of health and wellbeing ${ }^{2}$. OHRQoL not only measures the influence of oral conditions on a person's physical, emotional and social wellbeing, but also evaluates the repercussions of dental treatment on his/her life $\mathrm{e}^{3,4}$.

Oral conditions can affect the quality of life of children and adolescents and may have impact on their daily activities, including eating, sleep, speech, communication, and social interaction, as well as on their self-esteem ${ }^{5}$. The presence of dental caries $^{6}$, malocclusion ${ }^{7}$, and dental trauma ${ }^{8}$ has been associated with a negative impact on child and adolescent quality of life. The impact of these and other oral disorders on child and adolescent quality of life has been measured by epidemiological research, which, in addition to clinical measurements, uses individuals' self-perception of their health and of how oral conditions impact their daily lives 9 .

The literature contains few epidemiological studies on rural populations ${ }^{10,11}$, in particular regarding the evaluation of oral health ${ }^{12}$. It is important to assess the rural population because it has different social characteristics from the urban population. Thus, the aim of this study was to assess the impact of oral conditions on the quality of life of early adolescents, aged 11 to 14 years, in the rural area of a Brazilian municipality.

\section{MATERIALS AND METHODS}

This study was approved by the Human Research Ethics Committee of the Federal University of Minas Gerais, registered under protocol number 07939819.1.0000.5149. The adolescents who agreed to participate in the study signed a voluntary informed assent form and their parents/guardians signed a voluntary informed consent form authorizing their children to take part in the study.

Participants, eligibility criteria, study setting and period of data collection

This cross-sectional study was conducted with early adolescents aged 11 to 14 years, of both sexes, living in the rural area of Paula Cândido, Minas Gerais, Brazil. Data were collected between April and November 2019. Adolescents who had undergone or were undergoing orthodontic treatment and those with syndromes or cognitive impairment were excluded from this study.

\section{Sample size calculation}

According to the Municipal Health Department, Paula Cândido has 255 adolescents aged 11 to 14 years who live in rural areas. Thus, the sample for this study was defined by calculating the sample for finite populations ${ }^{13}$ :

$$
n=\frac{N \times \hat{p} \times \hat{q} \times z_{a / 2}^{2}}{\hat{p} \times \hat{q} \times z_{a / 2}^{2}+(N-1) \times e^{2}}
$$

where $\mathrm{N}$ is the number of individuals in the finite population, $\mathrm{p}$ is the sample proportion (proportion of the impact of oral conditions on quality of life), $\mathrm{q}$ is the complement of the proportion (1-p), $\mathrm{z}$ is the confidence level ( $95 \%$ confidence interval), and e is the margin of error.

Considering the number of early adolescents aged 11 to 14 years living in rural areas as 255 , a $50 \%$ prevalence of the impact of oral conditions on their quality of life, a confidence level of $1.96(95 \%$ confidence interval), and a margin of error of $5 \%$, the minimum sample comprised 154 adolescents. As data would be collected in multiple settings (schools in Paula Cândido), an effect factor of 1.2 was employed to mitigate imprecision. Thus, the minimum sample size was 185 participants. To compensate for possible losses, $20 \%$ was added. Thus, the final sample was 222 adolescents from rural areas.

\section{Data collection}

OHRQoL was assessed using the short Brazilian version ${ }^{14}$ of the Child Perceptions Questionnaire (CPQ11-14), which consists of a set of questions that measure how oral conditions impact quality of life $\mathrm{e}^{15}$.

The short version of the CPQ11-14 consists of 16 questions distributed across four domains: oral symptoms, functional limitations, emotional wellbeing, and social wellbeing. Each question addresses the frequency of events in the past three months and a five-point response scale is used with 
the following options: never $=0$; once/twice $=1$; sometimes $=2$; often $=3$; and every day/almost every day $=4$. A higher score indicates more negative perception regarding the impact of oral conditions on quality of life ${ }^{14,15}$.

Oral health status was clinically evaluated by one trained examiner at public schools in Paula Cândido. Calibration for dental caries, dental trauma and malocclusion was performed before data collection. A lecturer in Pediatric Dentistry coordinated the calibration of the examiner. For the three oral conditions, inter- and intra-examiner agreement were above 0.70. The examiner wore personal protective equipment (disposable gloves, mask, white coat, cap, and protective glasses) and used equipment for clinical examination such as mouth mirrors, wooden spatulas, and clinical probes. A note-taker recorded appropriate notes on a clinical record sheet.

Dental caries was evaluated according to the decayed, missing and filled teeth index (DMFT), following World Health Organization (WHO) criteria ${ }^{16}$. Participants were examined and the number of teeth with dental caries, missing teeth, and filled teeth were recorded. Malocclusion was assessed according to the Dental Aesthetic Index (DAI). This index assesses 10 occlusal characteristics according to three components: dentition (number of missing incisors, canines, and premolars), crowding and/or spacing (crowding and/or spacing in the upper arch, crowding and/or spacing in the lower arch, greater upper anterior irregularity, greater lower anterior irregularity and diastema between the upper central incisors) and occlusion (overjet, anterior crossbite, open bite and anteroposterior molar relation). The value found for each occlusal characteristic was multiplied by its specific weight and added up. To this sum, the value 13 was added to obtain the final DAI score. According to their DAI score, the adolescents could be assigned to one of four groups of malocclusion severity: normal or mild malocclusion (DAI $\leq 25)$, definitive malocclusion $(26 \leq \mathrm{DAI} \leq 30)$, severe malocclusion $(31 \leq \mathrm{DAI}$ $\leq 35)$ or very severe malocclusion $(\mathrm{DAI} \geq 36)^{17}$. The analysis of dental trauma was based on the Andreasen classification, ${ }^{18}$ through which only the upper and lower incisors were evaluated. The teeth were classified as: without evidence of dental trauma, teeth with mild trauma (fracture involving only enamel), teeth with severe trauma (fracture involving dentin and fracture involving dentin and pulp) and teeth with trauma that had been filled ${ }^{19}$.

\section{Directed acyclic graph}

Adirected acyclic graph (DAG) ${ }^{20}$ was used to identify potential confounding factors for the association between oral conditions and the OHRQoL. The confounding variables $\operatorname{sex}^{21}$ and age $^{22}$, number of sibling $s^{23}$, parents' schooling $^{22}$, family income ${ }^{23}$, number of tooth-brushing times/day ${ }^{24}$ and visits to the dentist/year ${ }^{25}$ were incorporated into the model (Fig. 1).

\section{Statistical analysis}

Statistical analysis was performed using the Statistical Package for the Social Sciences (SPSS, version 23.0, SPSS Inc., Armonk, USA). A descriptive analysis was performed. For the assessment of the association of oral conditions with the total score and the scores of the CPQ1114 domains, regression models were used to control the influence of confounding variables. For the regression models, sex and dental trauma were analyzed as categorical variables. Age, number of siblings, parents' schooling, family income, number of tooth-brushing times, visits to the dentist, DMFT and malocclusion were analyzed as quantitative variables. The level of statistical significance was $p<0.05$.

\section{RESULTS}

Of the 222 adolescents from rural areas, 202 were evaluated. Of these, 94 (46.5\%) were male and $108(53.5 \%)$ female. Mean age was 12.64 years $( \pm$ 1.09). The regression models showed that

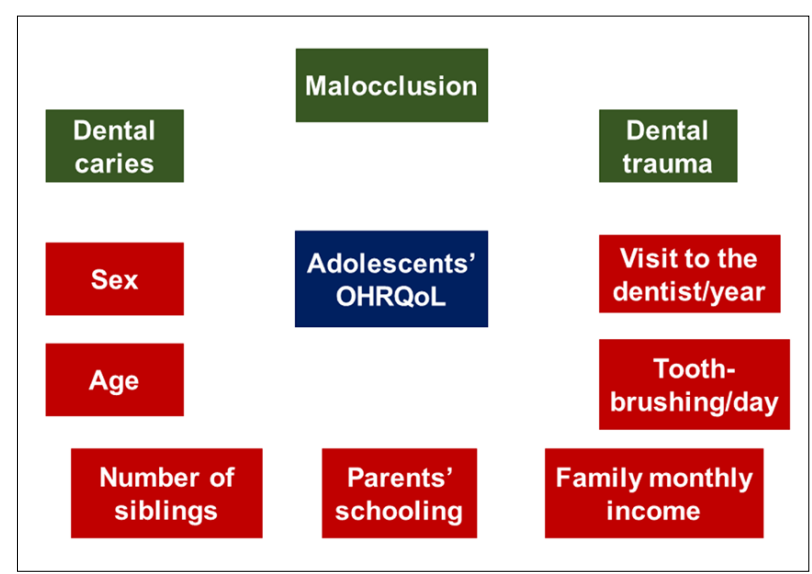

Fig. 1: Directed acyclic graph 


\begin{tabular}{|c|c|c|}
\hline & \multicolumn{2}{|c|}{$\begin{array}{l}\text { Total CPQ11-14 } \\
\text { score }\end{array}$} \\
\hline & $\begin{array}{l}\text { Coefficient } \\
\text { (SE) }\end{array}$ & $p$-value \\
\hline Sex (female*/male) & $-1.91(1.17)$ & 0.105 \\
\hline Age (years) & $0.39(0.54)$ & 0.473 \\
\hline Number of siblings & $0.46(1.19)$ & 0.698 \\
\hline Parents' schooling (in years) & $-0.88(1.24)$ & 0.480 \\
\hline Family income (BMW) & $-1.83(0.89)$ & 0.042 \\
\hline $\begin{array}{l}\text { Number of tooth-brushing } \\
\text { times (daily) }\end{array}$ & $-0.97(1.26)$ & 0.438 \\
\hline $\begin{array}{l}\text { Visits to the dentist (during the } \\
\text { year) }\end{array}$ & $-1.74(1.18)$ & 0.142 \\
\hline DMFT & $-0.04(0.19)$ & 0.801 \\
\hline $\begin{array}{l}\text { DT (without trauma*/enamel/ } \\
\text { dentin-pulp) }\end{array}$ & $0.51(1.09)$ & 0.638 \\
\hline Malocclusion (DAI) & $0.15(0.07)$ & 0.037 \\
\hline \multicolumn{3}{|c|}{$\begin{array}{l}\text { BMW=Brazilian minimum wage, DMFT=decayed, missing and } \\
\text { filled teeth index, DT=dental trauma, DAl= dental aesthetic index, } \\
\text { SE=standard error, } p \text {-value in bold indicates statistical significance. } \\
\text { Sex and DT were analyzed as categorical variables. Age, number of } \\
\text { siblings, parents' schooling, family income, number of tooth-brushing } \\
\text { times, visits to the dentist, DMFT and malocclusion were analyzed as } \\
\text { quantitative variables. } \\
\text { 'Reference variable }\end{array}$} \\
\hline
\end{tabular}

adolescents whose families had a lower monthly income ( $p=0.042)$ and adolescents with more severe malocclusion $(p=0.037)$ had a higher total CPQ1114 score (Table 1). Adolescents with more severe malocclusion also scored higher in the emotional wellbeing domain $(p=0.009)$. Finally, females scored higher than males in the oral symptoms domain $(p=0.002)$, and adolescents from lower income families scored higher in the social wellbeing domain ( $p=0.006)$ (Table 2).

\section{DISCUSSION}

The aim of this study was to assess the impact of oral status on the OHRQoL of adolescents in rural areas. The results showed that subjects whose families had a lower monthly income and subjects with more severe malocclusion had a more negative perception of their OHRQoL. The main negative effect of malocclusion was on the emotional wellbeing domain. There is growing awareness that oral disorders can significantly impact young people's physical, social, and psychological wellbeing. Malocclusion may have undesirable emotional and social effects ${ }^{26}$. This negative impact is likely due to the aesthetic impairment that dental and/or skeletal discrepancies can cause on the individual's face. An altered smile or an unfavorable facial appearance can cause psychological discomfort in young people affected by malocclusion, inhibiting them from maintaining social interactions with their peers. The fear of maintaining interpersonal relationships may occur due to the adolescent's growing apprehension of being a target of pejorative comments related to his/her dentofacial characteristics, which can produce feelings of inferiority and low selfesteem $^{7,27}$.

According to the results of this study, the main negative impact of the family income variable is on the social well-being domain. Socioeconomic factors during adolescence can lead to inequalities in general and in the oral health of individuals from less privileged social strata ${ }^{23}$. The impact of socioeconomic factors such as family income on an adolescent's social wellbeing and OHRQoL can be explained by material or psychosocial mechanisms ${ }^{28,29}$. Regarding the material issues, low family income can be one of the main barriers to access dental care services, where the individual can be advised regarding preventive measures and treated $^{23}$. Psychosocial issues, on the other hand, address each individual's experience related to social inequality, under psychological stress and lack of social protection, which can contribute to worsening his/her oral health and ultimately impair his/her OHRQoL ${ }^{30,31}$.

The results of the present study also demonstrated that female adolescents from rural areas had a more negative perception of the oral symptoms domain compared to male adolescents. Previous studies have highlighted the individual's sex as a variable of significant influence on adolescents' quality of life $^{32,33}$. Differences related to sex can influence the way the individual responds to the presence of health issues/oral conditions or to a medical/dental treatment, which reflect on the quality of life and its domains ${ }^{34}$. In addition, several articles in the literature show that women are more concerned with health and oral health and seek more dental treatment than men, as the presence of any oral disorder has more negative repercussions on their quality of life $\mathrm{e}^{21,35,36}$.

This study presents some limitations due to its crosssectional design, as it was not possible to directly determine cause-and-effect relationship between the 
Table 2: Regression model evaluating the association of CPQ11-14 domain scores with oral conditions and confounding variables

Sex (female*/male)
Age (years)
Number of siblings
Parents' schooling (in years)
Family income (BMW)
Number of tooth-brushing times (daily)
Visits to the dentist (during the year)
DMFT
DT (without trauma*/enamel/dentin-pulp)
Malocclusion (DAI)

Functional limitations

Sex (female*/male)

Age (years)

Number of siblings

Parents' schooling (in years)

Family income (BMW)

Number of tooth-brushing times (daily)

Visits to the dentist (during the year)

DMFT

DT (without trauma*/enamel/dentin-pulp)

Malocclusion (DAI)

Emotional well-being

Sex (female*/male)

Age (years)

Number of siblings

Parents' schooling (in years)

Family income (BMW)

Number of tooth-brushing times (daily)

Visits to the dentist (during the year)

DMFT

DT (without trauma*/enamel/dentin-pulp)

Malocclusion (DAI)

\section{Social well-being}

Sex (female*/male)

Age (years)

Number of siblings

Parents' schooling (in years)

Family income (BMW)

Number of tooth-brushing times (daily)

Visits to the dentist (during the year)

DMFT

DT (without trauma*/enamel/dentin-pulp)

Malocclusion (DAI)

Coefficient (SE)
$-1.08(0.35)$
$-0.02(0.16)$
$0.46(0.35)$
$0.52(0.37)$
$-0.07(0.26)$
$-0.18(0.37)$
$-0.35(0.35)$
$0.06(0.05)$
$-0.04(0.32)$
$0.02(0.02)$

p-value

0.002

0.871

0.195

0.162

0.787

0.628

0.311

0.238

0.881

0.337

Coefficient (SE)

$-0.36(0.35)$

p-value

$0.17(0.16)$

0.308

$0.34(0.36)$

0.289

0.341

0.07 (0.37)

0.850

$0.45(0.27)$

0.100

$-0.02(0.38)$

0.949

$-0.67(0.36)$

0.064

$-0.01(0.05)$

0.785

$-0.05(0.33)$

0.864

$0.02(0.02)$

0.360

Coefficient (SE)

p-value

$-0.33(0.46)$

0.472

$0.16(0.21)$

0.439

$-0.34(0.46)$

0.463

$-0.93(0.48)$

0.057

$-0.61(0.35)$

0.081

$-0.65(0.49)$

0.188

$-0.27(0.46)$

0.548

$-0.03(0.07)$

0.644

$0.25(0.43)$

0.552

0.07 (0.02)

0.009

Coefficient (SE)

p-value

$-0.13(0.33)$

0.686

$0.07(0.15)$

0.619

$-0.01(0.33)$

0.992

$-0.54(0.34)$

0.121

$-0.69(0.25)$

$\mathbf{0 . 0 0 6}$

$-0.12(0.35)$

0.734

$-0.43(0.33)$

0.190

$-0.06(0.05)$

0.225

$0.36(0.30)$

0.233

$0.03(0.02)$

0.079

$\mathrm{BMW}=$ Brazilian minimum wage, $\mathrm{DMFT}=$ decayed, missing and filled teeth index, $\mathrm{DT}=$ dental trauma, $\mathrm{DAl}=$ dental aesthetic index, $\mathrm{SE}=\mathrm{standard}$ error, $p$-value in bold indicates statistical significance. Sex and DT were analyzed as categorical variables. Age, number of siblings, parents' schooling, family income, number of tooth-brushing times, visits to the dentist, DMFT and malocclusion were analyzed as quantitative variables 'Reference variable 
independent variables and the OHRQoL outcome ${ }^{37}$. Another limitation is the fact that the sample is restricted to rural adolescents aged 11 to 14 years from a single Brazilian municipality. Thus, the external validity of these findings is limited and the results of this study should be used with caution when applied to rural populations with different characteristics from the population investigated herein.

In view of the results obtained, the present study may be useful for proposing and designing public health policies and services aimed specifically at populations living in rural areas. Rural populations, in general, use fewer health services ${ }^{38}$. The difficulties encountered by this population, such as lack of transportation, great distances to healthcare facilities, lack of means of communication, and low

\section{ACKNOWLEDGMENTS}

We thank the Secretary of Education of Minas Gerais and the Secretary of Education of Paula Cândido, who allowed the researchers to collect data at the schools.

\section{DECLARATION OF CONFLICTING INTERESTS}

The authors declared no potential conflicts of interest with respect to the research, authorship, and/or publication of this article.

\section{REFERENCES}

1. Locker D, Allen F. What do measures of 'oral healthrelated quality of life' measure? Community Dent Oral Epidemiol 2007;35:401-411.

2. Allison PJ, Locker D, Feine JS. Quality of life: A dynamic construct. Soc Sci Med. 1997;45(2):221-30. Soc Sci Med 1997;45:221-230.

3. Sischo S, Broder HL. Oral health- related quality of life: what, why, how, and future implications. J Dent Res 2011;90:1264-1270.

4. Bennadi D, Redvv CVK. Oral health related quality of life. J Int Soc Prev Community Dent 2013;3:1-6.

5. Mcgrath C, Bedi R. Can dental attendance improve quality of life? Br Dent J 2001;190:262-265.

6. Leal SC, Bronkhorst EM, Fan M, Frencken JE. Untreated cavitated dentine lesions: impact on children's quality of life. Caries Res 2012;46:102-106.

7. De Oliveira CM, Sheiham A. Orthodontic treatment and its impact on oral healthrelated quality of life in Brazilian adolescents. J Orthod 2004;31:20-27.

8. Gomes MC, Pinto-Sarmento TC, Costa EM. Martins CC, Granville-Garcia AFE, Paiva SM. Impact of oral health conditions on the quality of life of preschool children and income $^{23}$ can make it difficult for adolescents to access oral health services ${ }^{27}$. Thus, public policies are essential to facilitate their access to dental care services. Such services should also focus on guiding and advising their users, in addition to providing prevention measures and early treatment of certain oral disorders, such as malocclusion, to improve oral health status and provide better quality of life for adolescents living in rural areas ${ }^{39}$.

\section{CONCLUSION}

Malocclusion affected the quality of life of adolescents from the rural area of a Brazilian municipality, with a significant negative effect on their emotional well-being. A negative impact was also observed among individuals from lower income families and among females.

\section{FUNDING}

This study was funded in part by Coordenação de Aperfeiçoamento de Pessoal de Nível Superior - Brasil (Capes) - Finance Code 001.

Support from Conselho Nacional de Desenvolvimento Científico e Tecnológico (CNPq) (404710/2018-2 and 310797/2019-5).

\section{CORRESPONDENCE}

Dr Lucas G. Abreu

Rua Maranhão, 1447 / 1101, Funcionários, Belo Horizonte

Minas Gerais, Brazil, 30150-338

lucasgabreu01@gmail.com

their families: a cross-sectional study. Health Qual Life Outcomes 2014;18;12:55.

9. Adulyanon S, Vourapukjaru J, Sheiham A. Oral impacts affecting daily performance in a low dental disease Thai population. Community Dent Oral Epidemiol 1996;24:385-389.

10. Teckle P, Hannaford P, Sutton M. Is the health of people living in rural areas different from those in cities? Evidence from routine data linked with the Scottish Health Survey. BMC Health Serv Res 2012;12:43.

11. Douthit N, Kiv S, Dwolatzky T. Biswas, S. Exposing some important barriers to health care access in the rural USA. Public Health 2015;129:611-620.

12. Johnson G, Wright FAC, Foster K. A longitudinal evaluation of the Rural Clinical Placement Program at the University of Sydney Dental School. Eur J Dent Educ 2019;23:e59-e70.

13. Kirkwood BR, Stern J. Essential of medical statistics. London, UK: Blackwell, 2003:413-428.

14. Torres CS, Paiva SM, Vale MP, Pordeus IA, Ramos-Jorge ML, Oliveira AC, Allison PJ. Psychometric properties of the Brazilian version of the Child Perceptions Questionnaire (CPQ11-14) - short forms. Health Qual Life Outcomes 2009; 17:43. 
15. Jokovic A, Locker D, Guyatt G. Short forms of the Child Perceptions Questionnaire for 11-14-year-old children (CPQ11-14): development and initial evaluation. Health Qual Life Outcomes 2006;19;4:4.

16. World Health Organization. Oral Health Surveys: Basic Methods. Geneva, Switzerland: World Health Organization,2013:31-51.

17. Jenny J, Cons NC. Establishing malocclusion severity levels on the Dental Aesthetic Index (DAI) scale. Aust Dent J 1996;41:43-46.

18. Andreasen JO, Andreasen FM, Andersson L. Textbook and color atlas of traumatic injuries to the teeth. Oxford, UK: Blackwell Munskgaard,2007:217-254.

19. Bendo CB, Paiva SM, Varni JW, Vale, MP. Oral healthrelated quality of life and traumatic dental injuries in Brazilian adolescents. Community Dent Oral Epidemiol 2014;42:216-223.

20. Textor J, Van Der Zander B, Gilthorpe MS, Liskiewicz M, Elison GT. Robust causal inference using directed acyclic graphs: the $\mathrm{R}$ package 'dagitty'. Int J Epidemiol 2016;45:1887-1894.

21. Locker D, Jokovic A, Clarke M. Assessing the responsiveness of measures of oral health-related quality of life. Community Dent Oral Epidemiol. 2004;32:10-18.

22. Guerra MJC, Greco RM, Leite ICG, Ferreira EF, Paula MVQ. Impact of oral health conditions in worker's quality of life. Cien Saude Colet. 2014;19:4777-4786.

23. Paula JS, Leite ICG, Almeida AB, Ambrosano GMB, Pereira $\mathrm{AC}$, Mialhe FL. The influence of oral health conditions, socioeconomic status and home environment factors on schoolchildren's self-perception of quality of life. Health Qual Life Outcomes. 2012;13;10:6.

24. Paunio P, Rautava P, Helenius $H$, Alanen P, Sillanpää M. The Finnish Family Competence Study: the relationship between caries, dental health habits and general health in 3-year-old Finnish children. Caries Res. 1993;27:154-60.

25. Cunha-Cruz J, Nadanosvsk P, Faertein E, Lopes CS. Routine dental visits are associated with tooth retention in brazilian adults: pró-saúde study. J Public Health Dent. 2004;64:216222.

26. Van Der Geld P, Oosterveld P, Van Heck G, KuijpersJagtman AM. Smile attractiveness. Self- -perception and influence on personality. Angle Orthod. 2007;77:759-765.
27. de Paula JS, Leite IC, Almeida AB, Ambrosano GM, Mialhe FL. The impact of socioenvironmental characteristics on domains of oral health-related quality of life in Brazilian schoolchildren. BMC Oral Health. 2013;13:1-8.

28. Moor I, Spallek J, Richter M. Explaining socioeconomic inequalities in self-rated health: A systematic review of the relative contribution of material, psychosocial and behavioural factors. J Epidemiol Community Health. 2017;71:565-575.

29. Sfreddo CS, Moreira CHC, Nicolau B, Ortiz FR, Ardengui, T. M. Socioeconomic inequalities in oral health-related quality of life in adolescents: a cohort study. Qual Life Res 2019;28:2491-2500.

30. Locker D. Measuring oral health: a conceptual framework. Community Dent Health 1988;5:3-18.

31. Shaw WC, Richmond S, O'brien KD, Brook P, Stephens CD. Quality control in orthodontics: indices of treatment need and treatment standards. Br Dent J 1991;170:107-112.

32. Kawamura M, Takase N, Sasahara H, Okada M. Teenagers' oral health and behavior in Japan: comparison by sex and age group. J Oral Sci 2008;50:167-174.

33. Sun L, Wong HM, Mcgrath CPJ. The factors that influence oral health-related quality of life in 15-year-old children. Health Qual Life Outcomes 2018;16:19.

34. Abu-Awwad M, Hemmings K, Mannaa S, Gill D, Gulamali A, Petrie A. Treatment outcomes and assessment of oral health related quality of life in treated hypodontia patients. Eur J Prosthodont Restor Dent 2017;25:49-56.

35. Broder HL, Slade GD, Caine R, Reisine S. Perceived impact of oral health conditions among minority adolescents. J Public Health Dent 2000;60:189-192.

36. Al Yami EA, Kuijpers-Jagman AM, Van't Hof MA. Orthodontic treatment need prior to orthodontic treatment and 5 years postretention. Community Dent Oral Epidemiol 1998;26:421-427.

37. Levin KA. Study design III: Cross-sectional studies. Evid Based Dent 2006;7:24-25.

38. Lishner DM, Rosenblatt RA, Baldwin L, Hart, LG. Emergency department use by the rural elderly. J Emerg Med 2000;18:289-297.

39. Thomson WM, Broder HL. Oral-health-related quality of life in children and adolescents. Pediatr Clin North Am 2018;65:1073-1084. 